\title{
JEKK
}

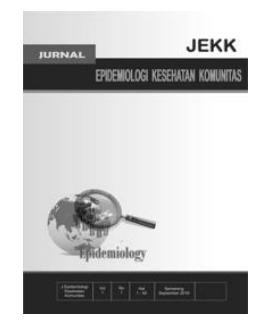

\section{Hubungan Indeks Massa Tubuh dan Tingkat Aktivitas Fisik dengan Kontrol Glikemik Diabetes Melitus Tipe 2}

\author{
Marisa Gita Putri*, Heri Nugroho Hario Seno **, Mateus Sakundarno Adi *** \\ *Program Studi Magister Epidemiologi, Sekolah Pascasarjana, Universitas Diponegoro \\ ** Departemen Ilmu Penyakit Dalam, Fakultas Kedokteran, Universitas Diponegoro \\ *** Program Studi Magister Epidemiologi, Sekolah Pascasarjana, Universitas Diponegoro
}

\begin{abstract}
Background: Diabetes mellitus (DM) type 2 is still a serious health problem in the world. Type 2 DM results from ineffective use of insulin by the body. Most people with type 2 diabetes worldwide are the result of being overweight and lacking physical activity. The purpose of this study was to determine the relationship of body mass index and physical activity with the glycemic control of type 2 DM patients.
\end{abstract}

Methods: This study used an observational study with a cross sectional design conducted at the Panti Wilasa Citarum Hospital in Semarang. The population in this study were outpatients at Panti Wilasa Citarum Hospital with a sample of 74 people. The sampling technique was consecutive sampling. Measurement of glycemic levels with HbA1c, body mass index based on weight and height, and physical activity with the PAR-WHO questionnaire. Data analysis uses the Spearman Rank correlation test.

Result: From 74 research respondents found $52.7 \%$ of respondents had bad glycemic control. There is a relationship between body mass index and poor glycemic control $(\mathrm{p}=0.041)$. There is no relationship between physical activity and poor glycemic control $(\mathrm{p}=0.437)$.

Conclusion: The advice given for respondents is to be able to maintain their diet and increase physical activity by exercising regularly.

Keywords: Body Mass Index; Glycemic Control; Physical Activity; Type 2 Diabetes Mellitus. 


\section{Pendahuluan}

Diabetes melitus (DM) adalah kelainan metabolik yang paling umum di seluruh dunia dan tingkat morbiditas yang tinggi, kualitas hidup yang rendah dan kematian tinggi. Diabetes melitus tipe 2 (non-insulin-dependent) dihasilkan dari penggunaan insulin yang tidak efektif oleh tubuh dan sebagian besar merupakan hasil dari kelebihan berat badan dan aktivitas fisik. ${ }^{1}$ Secara global, jumlah orang dengan diabetes terus meningkat. Penyakit ini telah mengenai sekurang-kurangnya $5-7 \%$ populasi dunia, dan prevalensinya diprediksi meningkat dari 171 juta orang pada tahun 2000 hingga 366 juta orang pada tahun 2030 dan $90 \%$-nya dapat menderita diabetes tipe $2 .{ }^{2}$

Diabetes merupakan masalah kesehatan dunia yang serius, dan salah satu penyakit yang memiliki kecenderungan memburuk. Diabetes tipe 2 secara metabolik bersifat progresif yang ditandai dengan kadar HbA1c selama perjalanan penyakit, walaupun terapi intensif diberikan, terutama akibat penurunan progresif fungsi sel beta. Diabetes tipe 2 sering kali tidak terdiagnosis dalam komunitas, dan $20 \%$ pasien yang terdiagnosis menderita diabetes berhubungan dengan komplikasi kardiovaskular. $^{3}$

Pengendalian kadar glikemik merupakan hal yang penting dalam penanganan DM. Dasar pengobatan diabetes tipe 2 berupa pengendalian status glikemik dengan melakukan gaya hidup sehat yang meliputi penerapan pola makan sehat, peningkatan aktivitas fisik, rencana berhenti merokok, dan pemeliharaan berat badan yang sehat ${ }^{4}$. Tujuan utama pengelolaan diabetes melitus adalah untuk menghadirkan kadar glikemik normal. ${ }^{5}$ HbA1c bermanfaat untuk kesintasan kontrol glikemik dalam menegakkan diabetes, namun indikator tersebut lebih penting sebagai uji (skrining) dan diagnostik primer. Hemogrobin A membentuk lebih dari $90 \%$ dari kebanyakan hemoglobin orang dewasa dan secara beragam mengandung glukosa akibat perlekatan gula bukan-enzim. HbA1c merupakan komponen glikemik utama dan telah terbukti dalam banyak studi berhubungan dengan glukosa darah rata-rata. Kunci utama terapi diabetes tipe 2 adalah diet dan modifikasi lain dari gaya hidup, seperti sering berolahraga dan berhenti merokok. ${ }^{6}$

Kontrol glikemik menjadi tujuan utama untuk pencegahan kerusakan organ target dan komplikasi lain yang timbul dari diabetes ${ }^{7}$. Berbagai faktor yang diidentifikasi dapat mempengaruhi kontrol glikemik diantaranya adalah usia, jenis kelamin, pendidikan, indeks massa tubuh, dan aktivitas fisik.

Diabetes melitus tipe 2 sering dikaitkan dengan kelebihan berat badan dan obesitas dan telah menjadi beban perawatan kesehatan publik selama beberapa tahun terakhir. Studi memperkirakan bahwa saat ini sekitar sepertiga populasi dunia kelebihan berat badan atau obesitas. $^{8}$ Beberapa penelitian bahkan menunjukkan bahwa risiko diabetes meningkat antara 4,5 dan 9\% untuk setiap kilogram kenaikan berat badan. ${ }^{9}$ Selain itu, obesitas terbukti menjadi faktor risiko independen untuk dislipidemia dan penyakit kardiovaskular dan penurunan berat badan dianggap sebagai ukuran kunci untuk manajemen DM tipe 2. Prevalensi obesitas pada pasien dengan diabetes dan penyakit kardiovaskular telah terbukti menjadi faktor risiko utama kematian dini. Risiko ini lebih rendah di antara individu dengan normal berat badan dan kontrol glikemik yang optimal. ${ }^{8}$ Kebanyakan orang dengan DM tipe 2 kelebihan berat badan atau obesitas, yang dapat menyebabkan atau memperburuk resistensi insulin. Banyak dari mereka yang tidak gemuk dengan kriteria IMT memiliki proporsi lemak tubuh yang lebih tinggi didistribusikan terutama di daerah perut, menunjukkan adipositas visceral dibandingkan dengan orang tanpa diabetes. ${ }^{10}$

Tingkat aktivitas fisik yang rendah juga mempengaruhi terjadinya diabetes tipe 2, mungkin karena olahraga meningkatkan sensitivitas insulin dan membantu untuk mencegah obesitas. Aktivitas fisik didefinisikan sebagai setiap gerakan tubuh yang dihasilkan oleh otot rangka yang membutuhkan pengeluaran energi. Setiap 
gerakan tubuh yang dihasilkan oleh otot rangka yang menghasilkan pengeluaran energi di atas tingkat istirahat (basal). Istilah ini secara luas mencakup latihan, olahraga, dan aktivitas fisik yang dilakukan sebagai bagian dari kehidupan sehari-hari, pekerjaan, rekreasi, dan lain sebaiknya. Aktivitas fisik dapat membantu penderita diabetes mencapai variasi tujuan, termasuk peningkatan kebugaran kardiorespirasi, meningkatkan kekuatan, peningkatan kontrol glikemik, penurunan resistensi insulin, peningkatan profil lipid, penurunan tekanan darah dan pemeliharaan penurunan berat badan.

Kasus penderita diabetes melitus di Kota Semarang terus mengalami peningkatan. ${ }^{11}$ Kasus diabetes melitus pada tahun 2014 berjumlah 9.772 hingga pada tahun 2018 meningkat pesat menjadi 48.996. Salah satu rumah sakit yang memiliki banyak kunjungan pasien diabetes melitus yakni Rumah Sakit Panti Wilasa Citarum. Penelitian mengenai status glikemik masih perlu diteliti, faktor tersebut diantaranya indeks massa tubuh dan aktivitas fisik terhadap kontrol glikemik penderita diabetes melitus tipe 2. Berdasarkan data dan kondisi tersebut maka penulis tertarik untuk menganalisis hubungan antara indeks massa tubuh dan aktivitas fisik dengan kontrol glikemik penderita diabetes melitus tipe 2 .

\section{Metode}

Jenis penelitian pada penelitian ini adalah penelitian yang bersifat observasional dengan desain cross sectional analitik. Variabel dependen yang akan dideskripsikan yaitu kontrol glikemik penderita diabetes melitus tipe 2. Variabel independen yang akan dideskripsikan adalah indeks massa tubuh dan aktivitas fisik.

Pengambilan sampel dalam penelitian ini menggunakan consecutive sampling. Populasi target pada penelitian ini adalah pasien rawat jalan diabetes melitus tipe 2. Sampel yang digunakan dalam penelitian ini berjumlah 74 orang. Pengukuran indeks massa tubuh dilakukan dengan mengukur berat badan dan tinggi badan. Aktivitas fisik diukur dengan pengisian kuesioner PAR-WHO. Kuesioner untuk menilai aktivitas fisik sudah tervalidasi dari the Joint FAO/WHO/UNU Expert Consultation on Human Energy Requirements. Instrumen pengumpulan data menggunakan pengukuran. Untuk pengukuran status glikemik dengan mengukur kadar HbA1c, indeks massa tubuh menggunakan timbangan dan microtoise. Pengukuran aktivitas fisik melalui kuesioner PAR-WHO

\section{Hasil}

\section{A. Karakteristik Responden}

Tabel 1. Distribusi Responden Menurut Umur, Jenis Kelamin, Pendidikan Terakhir, Pekerjaan

\begin{tabular}{|c|c|c|}
\hline $\begin{array}{r}\text { Karakteristik } \\
\text { Responden } \\
\end{array}$ & $\begin{array}{c}\text { Frekuensi } \\
(\mathbf{n})\end{array}$ & $\begin{array}{c}\text { Persentase } \\
(\%)\end{array}$ \\
\hline \multicolumn{3}{|l|}{ Umur } \\
\hline $41-45$ & 2 & 2,7 \\
\hline $46-50$ & 8 & 10,8 \\
\hline $51-55$ & 17 & 23,0 \\
\hline $56-60$ & 21 & 28,4 \\
\hline $61-65$ & 17 & 23,0 \\
\hline $66-70$ & 5 & 6,8 \\
\hline $71-75$ & 3 & 4,1 \\
\hline $76-80$ & 1 & 1,4 \\
\hline \multicolumn{3}{|l|}{ Jenis Kelamin } \\
\hline Perempuan & 41 & $\overline{55,4}$ \\
\hline Laki-laki & 33 & 44,6 \\
\hline \multicolumn{3}{|l|}{$\begin{array}{l}\text { Pendidikan } \\
\text { Terakhir }\end{array}$} \\
\hline Tidak Sekolah & 2 & 2,7 \\
\hline $\mathrm{SD}$ & 15 & 20,3 \\
\hline SMP & 7 & 9,5 \\
\hline SMA & 32 & 43,2 \\
\hline Perguruan Tinggi & 18 & 24,3 \\
\hline \multicolumn{3}{|l|}{ Pekerjaan } \\
\hline Tidak Bekerja & 5 & 6,8 \\
\hline Ibu Rumah & 31 & 41,9 \\
\hline Tangga & & \\
\hline Pensiunan & 13 & 17,6 \\
\hline PNS & 2 & 2,7 \\
\hline
\end{tabular}




\section{TNI/ POLRI}

Karyawan

BUMN/ Swasta

Wiraswasta/

Pedagang

Total

74

1

13

9

74

100,0

Karakteristik responden dari segi umur, responden paling banyak berada pada kategori umur 56-60 tahun $(28,4 \%)$ sementara umur paling sedikit kategori umur 76-80 tahun $(1,4 \%)$. Mayoritas jenis kelamin responden adalah perempuan $(55,4 \%)$. Pendidikan terakhir responden paling banyak tamat SMA $(43,2 \%)$, sedangkan yang paling sedikit tidak sekolah $(2,7 \%)$. (Tabel 1)

\section{B. Distribusi Frekuensi Kontrol Glikemik, Indeks Massa Tubuh, dan Aktivitas Fisik}

Pasien diabetes melitus tipe 2 yang memiliki kontrol glikemik buruk sebanyak $52,7 \%$, sedangkan pasien yang kontrol glikemik baik sebanyak 47,3\%. Indeks massa tubuh responden mayoritas memiliki tubuh obesitas $(58,1 \%)$ dan yang paling sedikit underweight hanya 1 responden $(1,4 \%)$. Mayoritas aktivitas fisik pasien diabetes melitus tipe 2 melakukan aktivitas ringan $(67,6 \%)$, sementara responden yang aktivitasnya berat hanya 1 responden $(1,4 \%)$.
Tabel 2. Distribusi Frekuensi Responden

\begin{tabular}{lrr}
\hline \multicolumn{1}{c}{ Variabel } & $\begin{array}{c}\text { Frekuensi } \\
(\mathbf{n})\end{array}$ & $\begin{array}{c}\text { Persentase } \\
(\boldsymbol{\%})\end{array}$ \\
\hline Kontrol Glikemik & & \\
\hline Buruk & 39 & 52,7 \\
Baik & 35 & 47,3 \\
\hline Indeks Massa & & \\
Tubuh & & \\
\hline Obesitas & 43 & 58,1 \\
Overweight & 11 & 14,9 \\
Normal & 19 & 25,7 \\
Underweight & 1 & 1,4 \\
\hline Aktivitas Fisik & & \\
\hline Ringan & 50 & 67,6 \\
Sedang & 23 & 31,1 \\
Berat & 1 & 1,4 \\
\hline
\end{tabular}

\section{Hubungan antara Indeks Massa Tubuh dengan Kontrol Glikemik}

Hasil penelitian yang terdapat pada tabel 3 menunjukkan bahwa proporsi kontrol glikemik buruk dengan indeks massa tubuh diperoleh sebagian besar responden obesitas $(22,7 \%)$ dan overweight hanya $5,8 \%$. Sementara untuk indeks massa tubuh normal $(10,0 \%)$ dan underweight dengan kontrol glikemik buruk $(0,5 \%)$.

Tabel 3. Tabulasi Silang Indeks Massa Tubuh dengan Kontrol Glikemik

\begin{tabular}{|c|c|c|c|c|c|c|}
\hline \multirow{3}{*}{$\begin{array}{c}\text { Indeks Massa } \\
\text { Tubuh }\end{array}$} & \multicolumn{4}{|c|}{ Kontrol Glikemik } & \multicolumn{2}{|c|}{ Jumlah } \\
\hline & \multicolumn{2}{|c|}{ Buruk } & \multicolumn{2}{|c|}{ Baik } & \multirow[t]{2}{*}{$\mathbf{n}$} & \multirow[t]{2}{*}{$\%$} \\
\hline & $\mathrm{n}$ & $\%$ & $\mathrm{n}$ & $\%$ & & \\
\hline Obesitas & 25 & 22,7 & 18 & 20,3 & 43 & 100,0 \\
\hline Overweight & 6 & 5,8 & 5 & 5,2 & 11 & 100,0 \\
\hline Normal & 8 & 10,0 & 11 & 9,0 & 19 & 100,0 \\
\hline Underweight & 0 & 0,5 & 1 & 0,5 & 1 & 100,0 \\
\hline Jumlah & 39 & 52,7 & 35 & 47,3 & 74 & 100,0 \\
\hline
\end{tabular}


Berdasarkan hasil uji statistik korelasi Rank Spearman diperoleh $\mathrm{p}=0,041$, hal ini menunjukkan ada hubungan antara indeks massa tubuh dengan kontrol glikemik. Dari hasil indeks massa tubuh dengan kontrol glikemik diperoleh nilai $\mathrm{r}=0,238$ menunjukkan hubungan sangat lemah dan arah hubungan positif, yang berarti semakin besar indeks massa tubuh semakin besar kadar glikemik atau kadar gula darah penderita DM tipe 2.
Dari grafik scatter plot 1 menggambarkan persebaran antara indeks massa tubuh dengan status glikemik. Dapat disimpulkan dari scatter plot ini nampak titik tersebar dan arah hubungan positif yang sangat lemah. Dalam artian indeks massa tubuh berpengaruh sangat lemah terhadap kontrol glikemik, yakni semakin besar indeks massa tubuh maka akan semakin besar kadar glikemik atau kadar gula darah dan akan berdampak kontrol glikemik buruk.

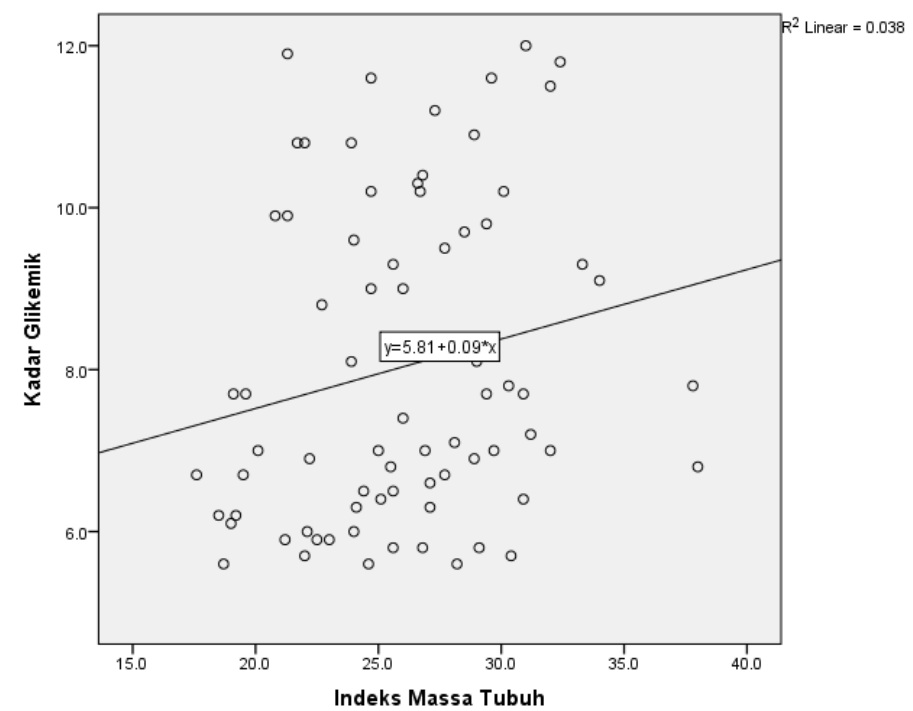

Gambar 1. Scatter Plot Indeks Massa Tubuh dengan Kontrol Glikemik

\section{Hubungan antara Aktivitas Fisik dengan Kontrol Glikemik}

Hasil penelitian yang terdapat pada tabel 4 menunjukkan bahwa proporsi status glikemik buruk pada pasien DM tipe 2 dengan aktivitas fisik yang ringan (26,4\%) lebih besar dibandingkan pada pasien dengan aktivitas sedang $(12,5 \%)$ maupun berat $(0,5 \%)$.

Tabel 4. Tabulasi Silang Aktivitas Fisik dengan Kontrol Glikemik

\begin{tabular}{|c|c|c|c|c|c|c|}
\hline \multirow{3}{*}{$\begin{array}{c}\text { Tingkat Aktivitas } \\
\text { Fisik }\end{array}$} & \multicolumn{4}{|c|}{ Status Glikemik } & \multicolumn{2}{|c|}{ Jumlah } \\
\hline & \multicolumn{2}{|c|}{ Buruk } & \multicolumn{2}{|c|}{ Baik } & \multirow[t]{2}{*}{ n } & \multirow[t]{2}{*}{$\%$} \\
\hline & $n$ & $\%$ & $\mathrm{n}$ & $\%$ & & \\
\hline Ringan & 31 & 26,4 & 19 & 23,6 & 50 & 100,0 \\
\hline Sedang & 7 & 12,1 & 16 & 10,9 & 23 & 100,0 \\
\hline Berat & 1 & 0,5 & 0 & 0,5 & 1 & 100,0 \\
\hline Jumlah & 39 & 52,7 & 35 & 47,3 & 74 & 100,0 \\
\hline Uji korel & an & & 0,4 & & & $-0,092$ \\
\hline
\end{tabular}


Berdasarkan hasil uji statistik korelasi Rank Spearman diperoleh $\mathrm{p}=0,437$, hal ini menunjukkan tidak ada hubungan yang signifikansi secara statistik ( $\mathrm{p}$ value $>0,05$ ) sehingga dapat disimpulkan bahwa tidak ada hubungan antara aktivitas fisik dengan kontrol glikemik pasien DM tipe 2. Kemudian diperoleh nilai $\mathrm{r}=-0,092$ menunjukkan arah hubungan negatif sangat lemah, yang berarti semakin besar aktivitas fisik semakin kecil kadar glikemik atau kadar gula darah pasien DM tipe 2. Untuk lebih jelasnya ditunjukkan dalam diagram scatter dibawah ini:

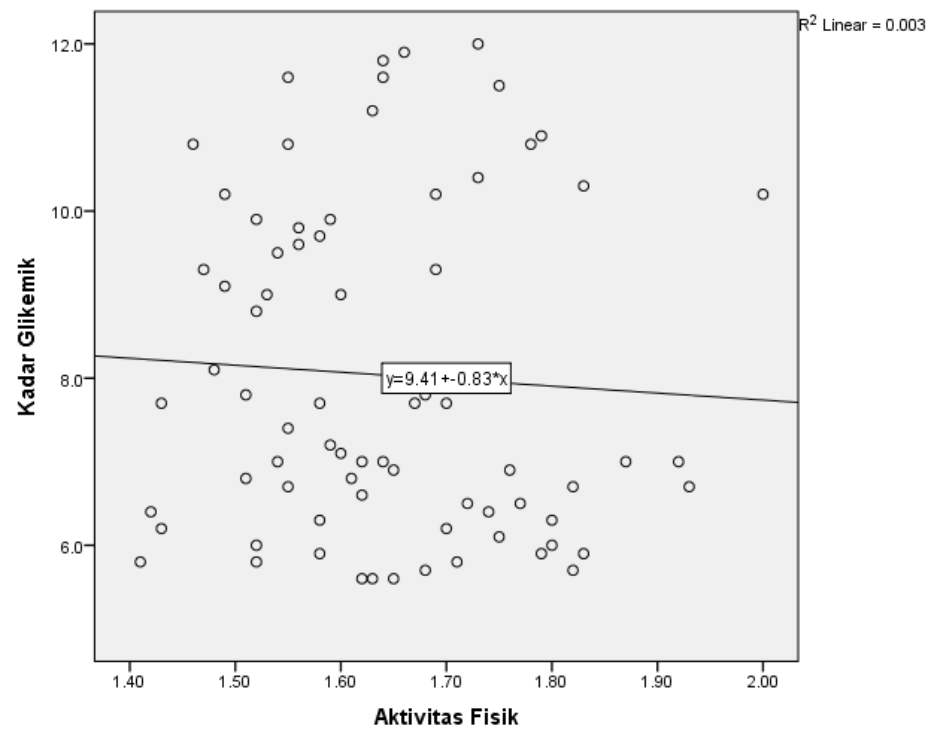

Gambar 2. Scatter Plot Aktivitas Fisik dengan Kontrol Glikemik

Dari grafik scatter plot 2 menggambarkan persebaran antara aktivitas fisik dinilai dari skor PAL akhir dengan kontrol glikemik. Dapat dilihat dari scatter plot grafik 2 nampak posisi titik tidak beraturan atau tidak linear dan garis menunjukkan hubungan negatif yang sangat lemah, artinya semakin besar aktivitas fisik maka akan semakin kecil kadar gikemik atau kadar gula darah sehingga kontrol glikemik menjadi baik.

\section{Pembahasan}

\section{Hubungan Indeks Massa Tubuh dengan Kontrol Glikemik}

Kelebihan berat badan dan obesitas adalah faktor penting yang dapat dimodifikasi yang mempengaruhi kontrol glikemik buruk dan risiko diabetes. ${ }^{12}$ Penelitian sebelumnya telah melaporkan bahwa kontrol glikemik pasien dengan DM tipe 2 umumnya memburuk ketika mereka bertambah berat badannya dan membaik ketika menurunkan berat badan. ${ }^{13}$ Sebuah studi yang menilai data dari pasien diabetes yang termasuk dalam Survei Pemeriksaan Kesehatan dan Gizi Nasional yang berlangsung di AS dari tahun 1999 hingga 2006 mengungkapkan bahwa tingkat $\mathrm{HbA} 1 \mathrm{c}$ rata-rata tertinggi dalam kasus penderita diabetes dengan BMI $>25 \mathrm{~kg} / \mathrm{m}^{2}$. Studi ini menunjukkan bahwa sekitar setengah dari orang dewasa dengan diabetes termasuk dalam kategori obesitas dan hampir seperempat orang dewasa pasien diabetes berjuang dengan suboptimal kontrol glikemik. Ini juga menunjukkan implikasi positif dari pencegahan obesitas dan penurunan berat badan melalui tindakan medis atau bedah dalam mengurangi beban diabetes pada sistem perawatan kesehatan. ${ }^{14}$

Banyak faktor yang terkait dengan proses mencapai kontrol glikemik yang ditargetkan, seperti kepatuhan terhadap pengobatan, adanya komorbiditas dan komplikasi, menunjukkan bahwa pendekatan perawatan bertahap harus dipertimbangkan untuk mendapatkan pengobatan yang sukses bagi pasien DM. Perhatian harus diberikan pada semua faktor risiko yang berpotensi mempengaruhi DM 
manajemen, terutama obesitas, karena prevalensi tinggi di antara pasien diabetes. Langkah-langkah yang efisien harus diambil untuk mencegah atau mengobati obesitas karena merupakan faktor yang dapat dimodifikasi dengan dampak besar pada banyak penyakit kronis termasuk diabetes dan patologi kardiovaskular. ${ }^{8}$

Mekanisme yang mungkin di balik hubungan kontrol glikemik yang buruk dengan peningkatan indeks massa tubuh adalah karena memperburuk resistensi insulin karena peningkatan massa lemak dan adipositas visceral, yang mempengaruhi sensitivitas insulin dan menyebabkan resistensi insulin. Adipositas menyebabkan lebih banyak pelepasan adipokin seperti resistin, retinol binding protein-4 dan mengurangi pelepasan adiponektin dan leptin ke dalam sirkulasi. Resistin bertanggung jawab atas resistensi insulin. Biasanya leptin dan adiponektin meningkatkan sensitivitas insulin memicu aksi enzim protein kinase teraktivasi AMP. Enzim protein kinase ini pada gilirannya merangsang oksidasi asam lemak di hati dan otot rangka. Pada akhirnya peningkatan resistin dan penurunan adiponektin secara kolektif menurunkan sensitivitas insulin dalam jaringan target. ${ }^{15,16}$

Obesitas terjadi dari tidak seimbangnya antara asupan energi sehingga terdapat kelebihan energi yang disimpan dalam bentuk jaringan lemak. Ketika seseorang menderita obesitas maka akan terjadi resistensi sel terhadap insulin akibat dari penimbunan lemak di jaringan kulit. Hal tersebut menyebabkan glukosa tidak dapat masuk ke dalam sel sehingga terjadi peningkatan kadar gula darah. ${ }^{17}$

Hal ini sejalan dengan penelitian Kisningsih menunjukan bahwa obesitas kelas 1 dan hiperglikemia grade 2 masih menjadi permasalahan komorbiditas diabetes melitus. Hasil antara IMT dan status glikemik saling berhubungan $(\mathrm{p}=0,004$ atau $\mathrm{p}<0,05){ }^{18}$ Penderita diabetes yang memiliki kelebihan berat badan atau overweight diketahui memiliki kadar gula darah yang tidak terkendali, sedangkan penderita yang memiliki berat badan normal kadar gula darahnya terkendali dengan baik. ${ }^{19}$
Berbeda dengan hasil Mewarnis, berdasarkan hasil analisis bivariat terhadap variabel obesitas dengan nilai $\mathrm{p}=0,796$. Hasil analisis tersebut menunjukkan bahwa obesitas tidak berpengaruh terhadap status kontrol glikemik. Hal tersebut membuktikan bahwa hipotesis ditolak, sehingga obesitas bukan merupakan faktor risiko terhadap status kontrol glikemik. $^{20}$

\section{Hubungan Tingkat Aktivitas Fisik dengan Kontrol Glikemik}

Manajemen glukosa, terutama setelah makan, bisa menjadi tantangan bagi individu dengan diabetes melitus tipe 2. Penelitian ini memanfaatkan latihan dengan cara yang unik sebagai intervensi untuk membantu mengendalikannya. ${ }^{21}$ Prognosis untuk diabetes tipe 2 dan resistensi insulin telah terbukti dapat dikelola untuk beberapa individu melalui modifikasi gaya hidup (yaitu, pembatasan kalori moderat dan aktivitas fisik teratur). Namun bentuk perawatan ini sangat kurang dimanfaatkan, meskipun merupakan salah satu yang termudah dan paling aman untuk direkomendasikan. $^{22}$

Latihan fisik adalah metode pengobatan dan pencegahan diabetes melitus tipe 2 yang sangat efektif. Aktivitas fisik mempengaruhi beberapa aspek diabetes melitus tipe 2, termasuk konsentrasi glukosa darah, resistensi insulin, tekanan darah, lipid darah, berat badan, dan distribusi lemak tubuh. ${ }^{23}$ Berjalan adalah salah satu aktivitas fisik paling umum dalam kehidupan sehari-hari. ${ }^{24}$ Namun pada penelitian Colberg SR et al., 54,6\% pasien dengan diabetes melitus tipe 2 yang terlibat dalam aktivitas fisik jarang berjalan, menunjukkan bahwa pasien dengan diabetes melitus tipe 2 harus berjalan lebih sering. ${ }^{25}$

Penelitian ini menunjukkan bahwa persentase tingkat aktivitas fisik responden dari yang terbesar adalah aktivitas fisik ringan. Hal ini terjadi karena mayoritas responden tidak bekerja dengan rata-rata umur adalah 58 tahun. Pekerjaan dan umur responden yang semakin menua inilah yang menyebabkan kecenderungan responden kurang dalam beraktivitas sehari-hari. Responden sebagian 
besar bekerja dalam posisi duduk dan lebih banyak menghabiskan waktu untuk aktivitas sedentari, seperti menonton tv.

Hasil penelitian membuktikan bahwa secara statistik tidak terdapat hubungan yang signifikan antara aktivitas fisik dengan kontrol glikemik pada penderita DM tipe 2 (p-value $=$ 0,648). Hasil penelitian ini sejalan dengan penelitian Nur yang membuktikan bahwa tidak terdapat hubungan yang signifikan antara aktivitas fisik dengan kadar gula darah pada pasien DM (p-value $=0,771) .{ }^{26}$

Aktivitas fisik pada penderita DM memiliki peranan penting dalam pengendalian kadar glukosa darah, khususnya bagi penderita DM tipe 2. Pada saat melakukan aktivitas fisik atau berolahraga, kebutuhan otot terhadap glukosa sebagai bahan bakar akan meningkat, sehingga terjadi peningkatan pemakaian glukosa oleh otot. Pada otot yang aktif karena aktivitas fisik, jumlah reseptor insulin pada sel tubuh serta sensitivitas reseptor terhadap insulin mengalami peningkatan. ${ }^{27}$

Berbeda dengan hasil penelitian Widodo, yaitu terdapat hubungan yang bermakna antara aktivitas fisik dengan kadar gula darah ( $\mathrm{p}$-value $=0,045) \cdot{ }^{28}$ Diketahui bahwa apabila aktivitas fisik yang dilakukan semakin berat, maka kadar gula darahnya semakin rendah. Apabila aktivitas fisik dilakukan secara teratur dan rutin maka akan memulihkan komposisi tubuh dengan cara menurunkan lemak abdominal adiposit, mampu memperbaiki homeostatis glukosa, dan sensitivitas insulin. ${ }^{29}$ Dengan semakin meningkatnya aktivitas fisik seseorang, tubuh akan lebih banyak menggunakan karbohidrat sebagai bahan bakar kerja otot yang kemudian akan mengeluarkan energi. Apabila tingkat aktivitas fisik yang dilakukan semakin berat, maka energi yang dikeluarkan oleh tubuh juga semakin tinggi. Sedangkan sumber energi manusia yang paling utama bersumber dari glukosa. Setiap orang yang melakukan aktivitas fisik, maka otot tubuh akan meningkatkan pembakaran glukosa secara maksimal. Sehingga aktivitas fisik menyebabkan peningkatan penyerapan glukosa ke otot yang bekerja dan akan diimbangi oleh produksi glukosa hepatik.

Pengaruh aktivitas fisik dalam latihan fisik berhubungan langsung dengan peningkatan kecepatan pemulihan glukosa otot (seberapa banyak otot mengambil glukosa dari aliran darah). ${ }^{30}$

Menurut Astuti, aktivitas fisik juga dapat mempengaruhi kadar gula darah. ${ }^{27}$ Berdasarkan latihan jasmani/olahraga diketahui bahwa proporsi responden terdistribusi merata antara kelompok yang rutin melakukan olahraga dengan yang jarang melakukan olahraga. Pada saat berolahraga, resistensi insulin berkurang, sebaliknya sensitivitas insulin meningkat, hal ini menyebabkan kebutuhan insulin pada pasien DM tipe 2 akan berkurang. Respons ini hanya terjadi setiap kali berolahraga, dan tidak merupakan efek yang menetap atau berlangsung lama.

\section{Kesimpulan}

Ada hubungan antara indeks massa tubuh dengan kontrol glikemik penderita DM tipe 2 . Tidak ada hungan antara tingkat aktivitas fisik dengan kontrol glikemik penderita DM tipe 2 . Disarankan agar penderita DM tipe 2 dapat menjaga pola makan dan dapat meningkatkan aktivitas fisik dengan berolahraga secara teratur.

\section{Ucapan Terima Kasih}

Ucapan terima kasih diberikan kepada Rumah Sakit Panti Wilasa Citarum Semarang yang telah memberikan ijin penelitian.

\section{Daftar Pustaka}

1. World Health Organization. 2018. Diabetes [Internet]. Available from: https://www.who.int/news-room/factsheets/detail/diabetes.

2. World Health Organization. 2016. Global report on diabetes. France.

3. International Diabetes Federation (IDF). 2013. Diabetes atlas sixth edition, international diabetes federation. 
4. International Diabetes Federation. 2017. IDF diabetes atlas eighth edition 2017 [Internet]. Available from: www.diabetesatlas.org.

5. Kumar V, RS Cotran, Robbins SL, 2005. Pathologic basic of disease 7th ed.vol.2. Elsevier Saunders. 756-760.

6. Bilous R, Donelly R. 2014. Buku pegangan diabetes edisi ke-4. Jakarta: Bumi Medika.

7. A Kakade A, R Mohanty I, Rai S. 2019. Assessment of factors associated with poor glycemic control among patients with type II diabetes mellitus. Integr Obes Diabetes. 4(3):1-6.

8. Mut-Vitcu G, Hudrea IC, Moşteoru S, Gaiţă L, Gaiţă D. 2017. Body mass index and glycaemic control in patients with Diabetes Mellitus: A case-control study. Rom J Diabetes, Nutr Metab Dis. 24(2):119-25.

9. Ganz ML, Wintfeld N, Li Q, Alas V, Langer J, Hammer M. 2014. The association of body mass index with the risk of type 2 diabetes: A case-control study nested in an electronic health records system in the United States. Diabetol Metab Syndr [Internet]. 2014;6(1):1-8. Available from:http://www.embase.com/search/result s? subaction=viewrecord $\% 7 \mathrm{~B} \& \% 7 \mathrm{Dfrom}=\mathrm{e}$ xport\%7B\&\%7Did=L372827357\%5Cnhttp ://dx.doi.org/10.1186/1758-5996-6

50\%5Cnhttp://zp9vv3zm2k.search.serialsso lutions.com/?sid=EMBASE\%7B\&\%7Dissn $=17585996 \% 7 \mathrm{~B} \& \% 7 \mathrm{Did}=\mathrm{doi}: 10.1186 \% 7 \mathrm{~B}$ $\% 25 \% 7 \mathrm{D} 2 \mathrm{~F} 175$

10. World Health Organization. 2019. Classification of diabetes mellitus.

11. Dinas Kesehatan Kota Semarang. 2018. Profil Kesehatan Kota Semarang 2018. Kota Semarang.
12. American Diabetes Association. 2016. Standards of medical care in diabetes. In: Diabetes Care.

13. Khattab M. 2010. Factors associated with poor glycemic control among patients with type 2 diabetes. J Diabetes Complications [Internet]. 24:84-89. Available from: www.jdcjournal.com.

14. Nguyen NT, Nguyen XMT, Lane J, Wang P. 2011. Relationship between obesity and diabetes in a US adult population: Findings from the national health and nutrition examination survey, 1999-2006. Obes Surg. 21(3):351-5.

15. Tripathy BB, Chandalia HB. 2012. RSSDI Text book of diabetes mellitus. 2nd ed. Jaypee Brothers Medical Publishers.

16. Bobby SK, Latha N. 2018. Impact of body mass index on glycemic control in type 2 diabetes mellitus. 17(11):32-5.

17. Amir SMJ D. 2015. Kadar glukosa darah sewaktu pada pasien diabetes mellitus tipe 2 di Puskesmas Bahu Kota Manado. J eBiomedik. 3(1):32-40.

18. Kisningsih. 2018. Hubungan antara body mass index dengan status glikemik.

19. Rahayu KB. 2018. Faktor-faktor yang berhubungan dengan kadar gula darah pada penderita diabetes melitus tipe 2 (studi pada wilayah kerja Puskesmas Kedungmundu Kota Semarang).

20. Meiwarnis R. 2016. Faktor risiko yang berpengaruh terhadap status kontrol glikemik pada kehamilan dengan diabetes melitus (studi kasus kontrol pasien di beberapa RS di Kota Semarang). J Epidemiol Kesehat Komunitas. 1(2):0-5. 
21. Bao W, Tobias DK, Bowers K, Chavarro J, Vaag A, Grunnet LG, et al. 2016. Physical activity and sedentary behaviors associated with risk of progression from gestational diabetes mellitus to type 2 diabetes mellitus: A prospective cohort study. Diabetes Technol Ther. 18:S83.

22. Nojima $H$, Yoneda $M$, Watanabe $H$, Yamane K, Kitahara Y, Sekikawa K, et al. 2017. Association between aerobic capacity and the improvement in glycemic control after the exercise training in type 2 diabetes Fred DiMenna. Diabetol Metab Syndr. 9(1):1-10.

23. Li L, Yin X, Yu D, Li H. 2016. Impact of physical activity on glycemic control and insulin resistance: A study of communitydwelling diabetic patients in eastern China. Intern Med. 55(9):1055-60.

24. Sigal RJ, Armstrong MJ, Bacon SL, Boulé NG, Dasgupta K, Kenny GP, et al. 2018 Clinical practice guidelines - physical activity and diabetes. Can J Diabetes. 42(1):54-63.

25. Colberg SR, Sigal RJ, Yardley JE, Riddell MC, Dunstan DW, Dempsey PC, et al. 2016. Physical activity/exercise and diabetes: A position statement of the American Diabetes Association. Diabetes Care. 39(11):2065-79.

26. Nur A. 2015. Kebiasaan aktivitas fisik pasien DM dengan kadar gula darah, Kolesterol, J Med Respati.

27. Astuti CM, Setiarini A. 2013. Faktor-faktor yang berhubungan dengan pengendalian kadar glukosa darah pasien diabetes melitus tipe 2 rawat jalan di Poliklinik Penyakit Dalam RSJ Prof. Dr. Soerojo Magelang Tahun 2013. Program Studi Gizi, Fakultas Kesehatan Masyarakat, Universitas Indonesia.
28. Widodo C. 2016. Hubungan aktivitas fisik, kepatuhan mengkonsumsi OAD dengan kadar gula darah pasien DM. J Sist Kesehat.

29. Kurniawan, Wuryaningsih. 2016. Rekomendasi latihan fisik untuk Diabetes Mellitus Tipe 2. J Berk Kedokt Duta Wacana. 4(11):913-21.

30. Abdurrachim R, Annisa RD. 2018. Fiber intake and physical excercise contributed to blood glucose level in outpatients with type 2 diabetes mellitus. J Gizi dan Diet Indones (Indonesian J Nutr Diet. 5(2):66. 